\title{
FAKTOR-FAKTOR YANG MEMPENGARUHI MAHASISWA AKUNTANSI DALAM PEMILIHAN KARIR MENJADI AKUNTAN PUBLIK
}

\author{
Janiman dan Asep Basuki \\ Universitas Swadaya Gunung Djati (UGJ) Cirebon \\ Email: jinyicrb@gmail.com dan asepbasuki2107@gmail.com
}

\begin{abstract}
Abstrak
Pemilihan karir merupakan harapan bagi seseorang akan sebuah karir yang dapat memenuhi kebutuhan dan juga mempunyai daya tarik tersendiri bagi mereka sedangkan akuntan publik merupakan salah satu dari profesi akuntan yang memiliki pekerjaan audit, akuntansi, pajak dan konsultan manajemen. Penelitian ini bertujuan untuk menganalisis pengaruh penghargaan finansial/gaji, lingkungan kerja, pelatihan profesional, pengakuan profesional, nilai-nilai sosial, pertimbangan pasar kerja, dan personalitas terhadap pemilihan karir menjadi akuntan publik. Penelitian ini menggunakan 181 responden mahasiswa jurusan akuntansi semester enam yang masih aktif diperkuliahan di kota Cirebon, dari data yang diperoleh dan dianalisis hanya 133 responden. Penelitian ini menggunakan metode survey dengan penyebaran kuesioner. Analisis data yang digunakan adalah analisis regresi logistik. Pengujian hipotesis dilakukan menggunakan uji t. Hasil penelitian ini menunjukkan bahwa penghargaan finansial/gaji, lingkungan kerja, pelatihan profesional, pengakuan profesional, nilai-nilai sosial, pertimbangan pasar kerja, dan personalitas tidak berpengaruh terhadap pemilihan karir menjadi akuntan publik.
\end{abstract}

Kata kunci: Penghargaan Finansial/Gaji, Lingkungan Kerja, Pelatihan Profesiona, Pengakuan Profesional, Nilai-Nilai Sosial, Pertimbangan Pasar Kerja, Personalitas, Pemilihan Karir Akuntan Publik.

\section{Pendahuluan}

Mahasiswa akuntansi yang telah menyelesaikan jenjang Strata satu (S1) dapat memilih pilihan alternatif pada karirnya. Pertama, mereka dapat langsung bekerja sebagai karyawan di sebuah perusahaan ataupun instansi pemerintah. Kedua, mereka dapat melanjutkan pendidikannya ke jenjang selanjutnya yaitu Pendidikan Strata dua (S2) bidang akuntansi atau pilihan alternatif ketiga yaitu menjadi akuntan publik. Pendidikan yang ditempuh untuk mendapatkan gelar akuntan bagi lulusan mahasiswa akuntansi S1 yaitu Pendidikan Profesi Akuntansi (PPAk). Laporan keuangan menjadi hal yang cukup penting dalam perusahaan, karena dengan melihat laporan keuangan yang dibuat dapat menganalisis bagaimana keadaan perusahaan, apakah mengalami kenaikan atau penurunan (Siagian \& Indra, 2019).

Surat Keputusan Menteri Pendidikan Nasional No. 179/U/2001 tentang penyelenggaraan Pendidikan Profesi Akuntansi (PPAk), dan Surat Keputusan Mendiknas No. 180/P/2001 tentang pengangkatan panitia ahli persamaan ijazah 
akuntan, serta ditandatanganinya Nota Kesepahaman (MoU) pada tanggal 28 Maret 2002, antara Ikatan Akuntan Indonesia (IAI) dengan Dirjen Dikti Depdiknas atas pelaksanaan pendidikan profesi akuntan, yang pada akhirnya Pendidikan Profesi Akuntansi (PPAk) di Indonesia dapat terealisasi setelah sekian lama ditunggu oleh berbagai kalangan khususnya para penyelenggara pendidikan akuntansi yang lulusannya tidak secara otomatis mendapatkan gelar dengan sebutan akuntan.

Pemerintah pada bulan Mei 2011, mengeluarkan UU No. 5 Tahun 2011 tentang profesi akuntan publik. Pemerintah secara jelas memperbaharui dan merevisi beberapa peraturan kembali tentang profesi akuntan publik.

Undang-Undang ini berisikan ruang lingkup jasa akuntan publik, perizinan akuntan publik, perpanjangan izin, hak, kewajiban, dan larangan bagi Akuntan Publik dan KAP, kerja sama antar Kantor Akuntan Publik (KAP) dan Kantor Akuntan Publik Asing (KAPA) atau Organisasi Audit Asing (OAA), Asosiasi Profesi Akuntan Publik, Organisasi Audit Indonesia (OAI), Standar Profesional Akuntan Publik (SPAP), pembinaan dan pengawasan oleh Menteri, sanksi administratif dan ketentuan pidana.

Peraturan dan kebijakan yang dikeluarkan pemerintah mengenai syarat menjadi seorang akuntan yang harus dipenuhi sesuai dengan UU No. 5 Tahun 2011 tentang profesi akuntan publik yaitu memiliki izin dari Menteri Keuangan yang berlaku selama 5 (lima) tahun, memiliki sertifikat yang menandakan telah lulus ujian profesi akuntan publik serta memiliki pengalaman praktik dalam memberikan jasa audit, jasa review dan jasa lainnya yang berkaitan dengan akuntansi, keuangan dan manajemen sesuai dengan ketentuan peraturan perundang-undangan.Berdasarkan UU No. 20 Tahun 2015 tentang profesi akuntan publik juga menjelaskan mengenai persyaratan untuk mengikuti ujian profesi akuntan publik yaitu seseorang harus memiliki pengetahuan dan kompetensi di bidang akuntansi atau telah terdaftar dalam register negara baik lulusan sarjana atau diploma empat (D-IV) dari berbagai macam jurusan dapat menjadi seorang akuntan, yakni akuntan publik manakala sudah mengikuti ujian sertifikasi secara khusus yang dilaksanakan oleh pemerintah.

Berdasarkan uraian di atas, peneliti tertarik untuk melakukan penelitian dengan judul "Analisis Faktor-Faktor Yang Mempengaruhi Mahasiswa Akuntansi Dalam Pemilihan Karir Menjadi Akuntan Publik (Studi Empiris pada Mahasiswa Akuntansi di Kota Cirebon)".

\section{Metode Penelitian}

Jenis penelitian yang digunakan adalah penelitian dasar sedangkan metode yang digunakan adalah deskriptif. Jenis data yang digunakan dalam penelitian ini merupakan kualitatif dengan sumber data primer melalui penyebaran kuesioner. Metode yang digunakan yaitu kuesioner dengan mendatangi responden, memberikan atau menyebarkan daftar pertanyaan kepada responden yaitu mahasiswa akuntansi S1 semester 6 (enam) yang masih aktif kuliah di Kota Cirebon (UNSWAGATI, UMC, STIE CIREBON dan STIE YASMI) lalu menanyakan kesediaannya untuk mengisi 
kuesioner. Penelitian ini menggunakan metode survey dengan penyebaran kuesioner. Analisis data yang digunakan adalah analisis regresi logistik.

\section{Hasil dan Pembahasan}

\section{Pengaruh Penghargaan Finansial/Gaji Terhadap Minat Akuntansi Dalam Pemilihan Karir Menjadi Akuntan Publik}

Berdasarkan hasil pengujian variabel penghargaan finansial/gaji terhadap pemilihan karir menjadi akuntan publik sebesar 0,130>0,05. Hal ini menunjukkan bahwa penghargaan finansial/gaji tidak berpengaruh terhadap minat mahasiswa akuntansi menjadi akuntan publik atau dengan kata lain hipotesis $\left(\mathrm{H}_{1}\right)$ tersebut tidak diterima. Hal tersebut didukung dengan penelitian terdahulu dengan hasil pengujian yang memiliki kesamaan bahwa penghargaan finansial/gaji tidak berpengaruh terhadap pemilihan karir mahasiswa akuntansi menjadi akuntan publik karena mahasiswa menganggap bahwa pekerjaan dengan gaji awal yang tinggi tidak menjadi prioritas utamanya karena kenaikan gaji secara bertahap yang mereka inginkan. Hasil dari penelitian (Merdekawati \& Sulistyawati, 2012; Setiawan, 2012) faktor Penghargaan Finansial/Gaji tidak berpengaruh terhadap pemilihan karir menjadi akuntan publik.

2. Pengaruh Lingkungan Kerja Terhadap Minat Akuntansi Dalam Pemilihan Karir Menjadi Akuntan Publik

Berdasarkan hasil pengujian variabel lingkungan kerja terhadap pemilihan karir menjadi akuntan publik sebesar 0,151>0,05 maka dapat disimpulkan bahwa variabel tersebut tidak memiliki pengaruh terhadap pemilihan karir menjadi akuntan publik. Hal ini menunjukkan bahwa lingkungan kerja berpengaruh terhadap minat mahasiswa akuntansi menjadi akuntan publik atau dengan kata lain hipotesis $\left(\mathrm{H}_{2}\right)$ tersebut tidak diterima.

Hal tersebut didukung dengan penelitian terdahulu dengan hasil pengujian yang memiliki kesamaan bahwa lingkungan kerja tidak berpengaruh terhadap pemilihan karir mahasiswa akuntansi menjadi akuntan publik karena mahasiswa menganggap bahwa bergantung pada hubungan kerja yang dijalin oleh mereka dan kondisi pekerjaan yang dijalani. Hasil dari penelitian (Apriliyan dan Laksito, 2011; Merdekawati \& Sulistyawati, 2012; Rahayu, 2003; Setiawan, 2012) faktor Lingkungan Kerja tidak berpengaruh terhadap pemilihan karir menjadi akuntan publik.

3. Pengaruh Pelatihan Profesional Terhadap Minat Akuntansi Dalam Pemilihan Karir Menjadi Akuntan Publik

Berdasarkan hasil pengujian pelatihan profesional terhadap pemilihan karir menjadi akuntan publik sebesar 0,753>0,05 maka dapat disimpulkan bahwa variabel tersebut tidak memiliki pengaruh terhadap pemilihan karir menjadi akuntan publik. Hal ini menunjukkan bahwa pelatihan profesional tidak berpengaruh terhadap minat mahasiswa akuntansi menjadi akuntan publik atau dengan kata lain hipotesis $\left(\mathrm{H}_{3}\right)$ tersebut tidak diterima. 
Hal tersebut didukung dengan penelitian terdahulu dengan hasil pengujian yang memiliki kesamaan bahwa pelatihan profesional tidak berpengaruh terhadap pemilihan karir mahasiswa akuntansi menjadi akuntan publik karena mahasiswa menganggap bahwa pengalaman kerja yang mereka inginkan dalam berkarir. Hasil dari penelitian (Merdekawati \& Sulistyawati, 2012; Rahayu, 2003) Pelatihan Profesional tidak berpengaruh terhadap pemilihan karir menjadi akuntan publik.

\section{Pengaruh Pengakuan Profesional Terhadap Minat Akuntansi Dalam Pemilihan} Karir Menjadi Akuntan Publik

Berdasarkan hasil pengujian variabel pengakuan profesional terhadap pemilihan karir menjadi akuntan publik sebesar 0,799>0,05 maka dapat disimpulkan bahwa variabel tersebut tidak memiliki pengaruh terhadap pemilihan karir menjadi akuntan publik. Hal ini menunjukkan bahwa pengakuan profesional berpengaruh terhadap minat mahasiswa akuntansi menjadi akuntan publik atau dengan kata lain hipotesis $\left(\mathrm{H}_{4}\right)$ tersebut tidak diterima.

Hal tersebut didukung dengan penelitian terdahulu dengan hasil pengujian yang memiliki kesamaan bahwa pengakuan profesional tidak berpengaruh terhadap pemilihan karir mahasiswa akuntansi menjadi akuntan publik karena mahasiswa menganggap bahwa miliki lebih banyak kesempatan agar dapat berkembang, pengakuan atas prestasi yang diraih, terdapat banyak cara agar dapat naik pangkat, dan memerlukan keahlian tertentu agar dapat mencapai kesuksesan tidak dibutuhkan. Hasil dari penelitian (Merdekawati \& Sulistyawati, 2012; Setiawan, 2012)Pengakuan Profesional tidak berpengaruh terhadap pemilihan karir menjadi akuntan publik.

5. Pengaruh Nilai-Nilai Sosial Terhadap Minat Akuntansi Dalam Pemilihan Karir Menjadi Akuntan Publik

Berdasarkan hasil pengujian variabel nilai-nilai sosial terhadap pemilihan karir menjadi akuntan publik sebesar 0,927>0,05 maka dapat disimpulkan bahwa variabel tersebut tidak memiliki pengaruh terhadap pemilihan karir menjadi akuntan publik. Hal ini menunjukkan bahwa nilai-nilai sosial berpengaruh terhadap minat mahasiswa akuntansi menjadi akuntan publik atau dengan kata lain hipotesis $\left(\mathrm{H}_{5}\right)$ tersebut tidak diterima.

Hal tersebut didukung dengan penelitian terdahulu dengan hasil pengujian yang memiliki kesamaan bahwa pengakuan profesional tidak berpengaruh terhadap pemilihan karir mahasiswa akuntansi menjadi akuntan publik karena mahasiswa menganggap bahwa pekerjaan dalam bidang apapun akan dapat terselesaikan dengan berbagai keahlian. Hasil dari penelitian (Merdekawati \& Sulistyawati, 2012; Setiawan, 2012) Nilai-Nilai Sosial tidak berpengaruh terhadap pemilihan karir menjadi akuntan publik.

6. Pengaruh Pertimbangan Pasar Kerja Terhadap Minat Akuntansi Dalam Pemilihan Karir Menjadi Akuntan Publik

Berdasarkan hasil pengujian variabel pertimbangan pasar kerjaterhadap pemilihan karir menjadi akuntan publik sebesar 0,478>0,05 maka dapat disimpulkan bahwa variabel tersebut tidak memiliki pengaruh terhadap pemilihan 
karir menjadi akuntan publik. Hal ini menunjukkan bahwa pertimbangan pasar kerja berpengaruh terhadap minat mahasiswa akuntansi menjadi akuntan publik atau dengan kata lain hipotesis $\left(\mathrm{H}_{6}\right)$ tersebut tidak diterima.

Hal tersebut didukung dengan penelitian terdahulu dengan hasil pengujian yang memiliki kesamaan bahwa pengakuan profesional tidak berpengaruh terhadap pemilihan karir mahasiswa akuntansi menjadi akuntan publik karena mahasiswa menganggap bahwa sekarang banyak sekali pekerjaan yang bersistem kontrak dan tidak sesuai dengan bidangnya semasa pendidikan dan dalam pekerjaan setelah menempuh pendidikan. Hasil dari penelitian (Asmoro dkk, 2015; Merdekawati \& Sulistyawati, 2012; Setiawan, 2012) Pertimbangan Pasar Kerja tidak berpengaruh terhadap pemilihan karir menjadi akuntan publik.

\section{Pengaruh Personalitas Terhadap Minat Akuntansi Dalam Pemilihan Karir Menjadi Akuntan Publik}

Berdasarkan hasil pengujian variabel personalitas terhadap pemilihan karir menjadi akuntan publik sebesar 0,608>0,05 maka dapat disimpulkan bahwa variabel tersebut tidak memiliki pengaruh terhadap pemilihan karir menjadi akuntan publik. Hal ini menunjukkan bahwa personalitas berpengaruh terhadap minat mahasiswa akuntansi menjadi akuntan publik atau dengan kata lain hipotesis $\left(\mathrm{H}_{7}\right)$ tersebut tidak diterima.

Hal tersebut didukung dengan penelitian terdahulu dengan hasil pengujian yang memiliki kesamaan bahwa pengakuan profesional tidak berpengaruh terhadap pemilihan karir mahasiswa akuntansi menjadi akuntan publik karena mahasiswa menganggap bahwa karir tersebut tidak mencerminkan personalitas seseorang yang bekerja secara profesional. Hasil dari penelitian Merdekawati (2011) Personalitas tidak berpengaruh terhadap pemilihan karir menjadi akuntan publik.

\section{Kesimpulan}

Hasil pengujian menunjukkan bukti bahwa persepsi mahasiswa terhadap faktor Penghargaan Finansial/Gaji, Lingkungan Kerja, Pelatihan Profesional, Pengakuan Profesional, Nilai-Nilai Sosial, Pertimbangan Pasar Kerja, dan Personalitas tidak berpengaruh dalam pemilihan karir menjadi akuntan publik.

Keterbatasan yang dimiliki dalam penelitian ini yaitu survei yang hanya dilakukan pada mahasiswa starta satu (S1) di universitas dan sekolah tinggi saja juga penelitian ini hanya menguji faktor yang telah diuji oleh peneliti sebelumnya.

Bagi peneliti selanjutnya diharapkan dapat menambah ruang lingkup penelitian dengan mengambil sampel lebih banyak lagi agar mendapatkan hasil yang lebih akurat lagi. Serta perlu diadakan lagi pengujian terhadap faktor-faktor lain sehingga dapat mempengaruhi minat mahasiswa akuntansi terhadap pemilihan karir menjadi akuntan publik. 


\section{BIBLIOGRAFI}

Apriliyan dan Laksito. (2011). Faktor-Faktor yang Mempengaruhi Mahasiswa Akuntansi Dalam Pemilihan Karir Menjadi Akuntan Publik. Jurnal Riset Akuntansi Indonesia, 3(2).

Asmoro dkk. (2015). Faktor-Faktor Yang Mempengaruhi Mahasiswa Akuntansi Dalam Pemilihan Karir Sebagai Akuntan Publik. Jurnal Ekonomi, 1(1).

Merdekawati, Dian Putri, \& Sulistyawati, Ardiani Ika. (2012). Faktor-faktor yang mempengaruhi pemilihan karir akuntan publik dan non akuntan publik. Jurnal Ilmu Ekonomi ASET, 13(1).

Rahayu, Dkk. (2003). Presepsi Mahasiswa Akuntansi Mengenai Faktor-Faltor Yang Mempengaruhi Pemilihan Karir. Simposium Nasional Akuntansi VI.

Setiawan, Chan A. (2012). Analisis Faktor-Faktor yang Mempengaruhi Pemilihan Karir Menjadi Akuntan Publik oleh Mahasiswa Jurusan Akuntansi. Jurnal Ilmiah Mahasiswa Akuntansi, 1(1).

Siagian, Ade Onny, \& Indra, Natal. (2019). Pengetahuan Akuntansi Pelaku Usaha Mikro Kecil dan Menengah (UMKM) Terhadap Laporan Keuangan. Syntax Literate; Jurnal Ilmiah Indonesia, 4(12), 17-35. 